\title{
The War of Shkodra in the Framework of the Balkan Wars, 1912-1913
}

\author{
Dr. Edit Bregu \\ Vice Dean/Lecturer, Law Faculty, \\ Wisdom University College, \\ Rruga Medar Shtylla, Komuna e Parisit, \\ Tirana 10oo, Albania \\ Dr. Irvin Faniko \\ Lecturer, Wisdom University College, \\ Rruga Medar Shtylla, Komuna e Parisit, \\ Tirana 10oo, Albania
}

DOI: https://doi.org/10.36941/jesr-2021-0013

\begin{abstract}
Before starting the First Balkan War, the Great Powers were not prepared for a quick victory of the young Balkan allies against an old empire, as it was until 1912 the Great Ottoman Empire. At the Ambassadors Conference in London, Austro-Hungary argued that the involvement of Shkodra City was essential to the economy of the new Albanian state. Meanwhile Russia did not open the way for solving the Shkodra problem, Russian diplomats thought how to satisfy Serbia's ambitions in Northeast Albania, respectively in Kosovo Beyond those considerations of a political character, on 8 October 1912, was the youngest member of the Balkan Alliance, the Shkodra northern neighbor, Montenegro, that rushed to launch military actions, thus opening the first campaign of the First Balkan War. The Montenegrin military assault, as its main strategic objective in this war, was precisely the occupation and annexation of the historic city of Shkodra, a city with a big economic and cultural importance for the Albanian people and territory.
\end{abstract}

Keywords: Shkodra, conference, diplomacy, war, annexation, Balkans

\section{Introduction}

In the most general, first and classical sense, war is an armed intervention between states or opposing forces, carried out through a series of battles. Whereas, according to a theoretical definition, already classical, made by the scholar, theorist and philosopher of the world military art, Clausewitz, war is a continuation of politics by other means (2008, p.63), which means the tools of violence. For these reasons the war has its relations with politics, in the service of which it is. At the same time, it maintains close and permanent relations with science and technology. Since modern times war has appeared to be quite closely linked to the state, the people or the nation and the army. Wars, as an act of violence, are general and partial, just as they are diverse, such as civil, terrorist, ethnic, religious, etc. Of course, wars have reasons why they happen. The Balkan wars were fought according to the same rules and 
principles. They had causes for which they ignited and developed. Most were of a political, social, economic, ethnic and religious nature. They have come as a result of prolonged conquests by various empires, which have brought with them, rooted and left behind many injustices in the division of territories or borders between the peoples and states of the Balkans. But wars have also occurred because of strife, strife, resentment, and hatred created as a result of living long lives in multi-ethnic empires or in states of mixed nationalities. Without excluding that those wars in the Balkan Peninsula have occurred due to the extreme nationalisms of the peoples or states of the Balkans, such as the Serbs, Bulgarians, etc., as well as have come even after liberation from occupation, to return more after in the wars for new conquests between the Balkan states themselves. Basically, they have had invasions, annexations and the forcible expansion of the borders of their territories by armies and weapons. The wars that took the initiative for such reasons, in the long history of the Balkan region, have been numerous. Only in the course of the twentieth century, in this region have developed, - as writes a researcher of Balkan issues of Balkan origin and Serbian nationality, - A total of seven wars (Kadare I, Simiç P, Frckskoski L, Hysa Y, Ballkani i Jugut, 200o, p. 41). Among them, or rather those who opened the door to the wars of the twentieth century, were found such essential and explosive causes, truly inevitable. Such were the political instability, but not only, the extreme extremism, the consequences of the decisions of the Treaty of St. Stephen and the Congress of Berlin, the effects of the Bosnian Crisis, the issue of Tripolitania and that of Macedonia. Simultaneously with them, but equally important were the decisions of the Great Powers of the post-Bismarck period, the aggravated socio-economic situation of the region and the explosions of the Albanian issue and factor in the Great Uprisings of 1910-1912. According to Antonello Biagini, Professor of History at the University of La Sapienza, the Ottoman occupation was long and difficult for the peoples of the Balkans. For centuries, the High Gate had created problems in the Balkans, both politically and religious. Ottoman power seemed impossible to break from the aspect of military organization, it had even created the belief that the war against the infidels was a really necessary mission to be carried out (Biagini, 2012, p. 14). But this conviction did not go on indefinitely. Once the Balkan countries realized that the situation had changed, they rushed to take advantage and think of a liberation war against several centuries of Ottoman invaders as possible. It was precisely these causes and the difficult situation, ruined politico-military and economic of Ottoman Turkey in 1912, that prompted the creation of the Balkan League and led the region to the First Balkan War, with the aim of forcing the Empire to leave the Balkans. The situation was clearly understood after the annexation of Bosnia. At this time in Serbia but also in other Balkan countries it was observed that only an alliance between them could permanently remove and end the Ottoman domination on the peninsula (Biagini, 2012, p. 14). While the ceasefire was signed between the Bulgarian army, which had reached near the city of Adrianople, where the forces of the Turkish army were defending, which was doing its best not to release it, in some Albanian territories the fighting continued. Among them were the heaviest fighting in two Albanian cities, Shkodra in the north, fighting heroically for months, surrounded by the Montenegrin army forces. The other town on the southern edge was Ioannina, which was defended by mixed Albanian and Ottoman armies. Meanwhile, in the North, a fierce and bloody, spontaneous battle took place in the province of Luma by Albanian volunteer fighters against a column of the Serbian army targeting the Albanian Adriatic coast. The fighting was very fierce and of a protracted character, the fate of which, in the end, would be decided by the decisions of the Great Powers. This situation is confirmed by historian Misha Glenny who write that the state of war continued in Ioannina and Shkodra, the southernmost and northernmost castles in Albania in the hands of the joint Turkish and Albanian forces. The Greeks refused to sign the ceasefire because they wanted to continue the siege of Ioannina. The commander of the Turkish garrison in Shkodra did not accept the terms of the ceasefire. So, the war went on... (Glenny, 2007, p. 240).

\section{Methodology}

Through this paper, we managed to use a qualitative research methodology, with primary and 
secondary data which are the result of reviewing a fairly extensive contemporary and archival literature regarding to the purpose of the study that this topic will follow to the researchers. The implementation and realization of the goals and objective, this study tries to achieve through the implementation of a scientific Methodology where the base is in-depth research and comparison, and analysis through the facts arising from archival sources in the historic area, documentary collections, as and utilization of assets, documentary material and published domestic and foreign historical literature. The primary research is based on quantitative research through archival sources in the Central Archive of the Republic of Albania, as well as Russian, French, Turkish, British, Serbian, Italian and Austrian archival documents.

\section{The Issue of Shkodra in the London Conference of Ambassadors}

Before starting the First Balkan War, the Great Powers were not prepared for a quick victory of the small Balkan allies over an old empire, as it was until 1912 the Great Ottoman Empire. But, as Richard C. Hall (2000, p. 72) writes, victory was quite natural, because of the significant moral, economic, and military progress that Christian states had made since their liberation. At the London Conference of Ambassadors, Austria-Hungary argued that the inclusion of Shkodra was essential for the economy of the new Albanian state. Russia did not pave the way for the solution of the Shkodra problem without fully satisfying Serbia's ambitions in the Northeastern of Albania, respectively in Kosovo. Beyond these assessments of a political nature, on October 8, 1912, was the smallest member of the Balkan Alliance, the northern neighbor of Shkodra, Montenegro which rushed to launch hostilities, thus opening the first campaign of the First Balkan War. The invasion of the Montenegrin military forces, as its main strategic objective in this war had exactly the occupation and annexation of the historical city of economic and cultural importance, Shkodra. On the other hand, both the Albanians and the military of the Turkish-Ottoman garrison based in this city, commanded by Colonel Hasan Rizai, were interested in the defense of the Shkodra's city. It was he, who was given the task of defending the northern Albania against Montenegro on September 18, 1912, together with 13,60o men of the Shkodra Corps, supported by 96 heavy weapons. This corps had active the 21st and 24th Divisions, Elbasan Reserves and Shkodra Divisions as well as the strong brigade Temporary Division, created by 4 active battalions and some mountain batteries. The 21st Division later became the Ipek Detachment (Contingent), composed of an ambitious Albanian officer, Brigadier General Esad Pasha (Toptani) (Hooton, 2014). According to Henry Barby (1913). The Montenegrins assembled in Podgorica 15,00o troops from the Zeta Corps, with 4o heavy weapons under the command of Prince Danilo who was to launch attacks on Shkodra from the east. The Coast Guard, with 8,ooo men and 34 heavy weapons under Brigadier General Miltar Martinovic, was advancing down the coast from Bar. Henry Barby was the special correspondent for The Spectator Magazine during the First Balkan War. He followed the Serb troops, and was present at the battles of Kumanovo, Prilep and Bitola. Later, after the ceasefire, he was again with the Serbian army in the final attack on Adrianople and also witnessed the capture of the castle. The admirable qualities of the Serbian army are emphasized by H. Barby, in his book "Les Victoires Serbes", and he is particularly concerned about highlighting their important role in the capture of Adrianople. The Albanians wanted to protect Shkodra from a new invader, who wanted to alienate the city and its inhabitants, while the Turks fought for their military and national dignity, not to fall captive to the Serbo-Montenegrins, as well as for their political and military interests. In response to German pressure not to disrupt the Conference, Austria-Hungary made a series of concessions until Russia agreed to leave Shkodra as part of Albania. Regarding this argument used by Austria-Hungary, the Russian Foreign Minister of those years, Sergey Dmitrievich Sazonov, also sheds light, who clearly describes the pressures exerted by the Slavic circles and King Nikola of Montenegro himself for the annexation of Shkodra by his state. 
Particularly a passionate attitude caused us the claims raised by King Nikola of Montenegro for the city of Shkodra and the province that belonged to it, he says (Sazonov, 2009, p. 101). Sazonov further reveals his views on the persistent Montenegrin nationalist demand through their highest representative, King Nikola, and the national historical truth of Shkodra as an entirely Albanian city. But he does not leave without expressing his "Slavic nationalist" obligation to influence the city to become Montenegro, despite the historical truth of the authentic national affiliation of Shkodra. Despite the undoubted Albanian character of the population of that country, the Russian government, if the solution of this problem depended only on its good will, would never oppose the fulfillment of the wish of "Russia's only friend, this would mean that, the representative of Russia would undoubtedly support the request for Shkodra to pass to Montenegro! In the face of such a "need", considered a priority for the Powers, but destructive for Albania, the British diplomacy tried to play the role of mediator. This forced him to give up some basic principles that are constantly positive towards the Albanian cause, crystallized especially in the Albanian crisis of 1911, which were based on the new wind that was blowing in British diplomacy. Among them we single out the memorandum sent by the American missionary Telford Erickson, to Sir Edward Gray. In that memorandum, Eriksson, after arguing with facts and historical documents the Illyrian-Arberian antiquity of the Albanians, asks that ... how can this ancient land and this ancient people be divided between the allies as a spoil of war?! He further added: We gentlemen have learned that justice must be the cornerstone of any lasting order in human society (PRO. FO. 371. 1823, doc. No. 25388, June 2, 1913).

\section{The Interim Government of Ismail Kemal and the Shkodra Issue}

The fight to defend the city had meanwhile become famous throughout Europe. Moreover, Europe became sensitive to reports of bombings against the civilian population and the diplomatic corps in Shkodra. To verify the reports of the newspapers and those of the foreign consuls there, the Conference of Ambassadors sent to the city a mission led by the Austrian military attaché to Cetina, Captain Hubka. He met with the Colonel Hasan Riza Pasha and the Deputy Commander Esat Pasha Toptani and realized that the city was approaching to the brink of starvation and that bombs had been dropped mercilessly on it. In response to this situation, the British Parliament held a discussion session on the siege of Shkodra and Foreign Minister Gray was called to give explanations. Gray delivered an open but very cynical speech. In essence he said that, we know that, after a while our children will see all this as a great injustice. The Chairman of the Provisional Government, Ismail Qemali, was extremely concerned about the Shkodra issue. He had always feared that the city might capitulate, before this city also came under the jurisdiction of the new Government of Albania. For this reason, he had decided to put everything in motion so that Shkodra would not fall under Montenegrin occupation (HHStA. PA. Report 26. 11. 1912, file 22-7). To pressure Montenegro to lift the siege, several Austro-Hungarian warships accompanied by Italian, British and French ships demonstrated in Adriatic waters opposite Bar, as they had done 40 years ago against Haxhi Zeka's troops defending Ulcinj from the Montenegrin occupation. According to the secret supplementary part of the Treaty of Alliance between Bulgaria and Serbia, dated February 29, 1912, Serbia was granted the right to take the Turkish territory until then in the North and West of the Sharr Mountain. In connection with this provision, and trying to provide their state with access to the sea, Serbian troops, on November 15, 1912, entered Lezha and, step by step, occupied the whole of northern Albania as far as Tirana. and Durrës. In the "Times" of London, on November 25, was published Pasic's statement that Serbia is looking for Durrës with the largest hinterland. In this process, over two thousand Matjans, led by Ahmet Zogu, were defeated by the Serbs in Lezha, while the Ottoman military troops, led by General Mahmut Hajret Pasha Jella, located in Berat, were nailed to the field of Myzeqe by the attack of joint Serbo-Bulgarian. 
Montenegro in these years, had a population of about 300,ooo inhabitants. Their capital, Cetina, writes the researcher Edith Durham, resembled a red-tiled village of about 3,0oo inhabitants and 8 times smaller than Shkodra (1991, p. 320). On October 8, 1912, Montenegro declared war on Turkey (as cited in History of Albania, 1956, p. 351-354). And, ironically, it was Montenegro that started the war first, a few days before the declaration of the First Balkan War by the member states of the Balkan Alliance against Turkey. On October 9, 1912, forces of the Montenegrin army fired cannon at the Albanian fortress of Deçan, where, a year earlier, the Albanian national flag had been raised. The Montenegrin Army, according to the History of the Albanian Military Art from Antiquity until 1939 (2001, p. 229), at the beginning of the Balkan War, in peacetime was based only on the militia, deprived of basic services such as health, transport. Referring to the book History of the Albanian Army 1912-1939 (2000), the army was organized in 4 divisions with 11 infantry brigades, a total of 52 battalions and 322 territorial detachments, with a total of 34,000 soldiers. However, this figure is debatable because different figures are given in different sources. According to this publication (2000) the figure is 31,00o Montenegrin soldiers. In the operation against Shkodra, the Montenegrin military forces were divided into three main groups: the North, the Center and the South or the Coast Group. Seen separately each of them, the composition, placement and purpose of each of them was as follows. Thus, the Northern Group was composed of 22 battalions and 6 artillery batteries, with a total of 10,000 men, was concentrated in the Zabjak region. The Center grouping, which was larger and concentrated in Podgorica, also consisted of 22 battalions and 11 artillery batteries, with a total force of 8,00o troops. In this operation, Montenegro concentrated in support of the forces 94 artillery shells (23 batteries), with a composition of $120 \mathrm{~mm}$ mortar; 75 and $87 \mathrm{~mm}$ field balls, but also 150 and $210 \mathrm{~mm}$ balls. (History of the Albanian Army, 2000, pp. 550-551). Of course, each group also had its own plan and direction of attack. In this operation, one of the longest in the First Balkan War, the High Command of Montenegro had defined as the main idea that, with the forces of the Northern Group, to occupy Plava, Guca, Peja and Gjakova and go to Prizren.

\subsection{The beginnings of the Montenegrin attacks on Shkodra}

Meanwhile, according to the History of the Albanian Military Art from Antiquity until 1939 (2001, p. 230), with the forces of the Central Group to attack in the main direction that was Podgorica-KoplikShkodra. This attack was aided by the attack of the Southern Group, which had to deliver the attack in the direction of Bar-Kraja-Tarabosh to capture, together with the forces of the Central Group, the city of Shkodra. After that, these forces would join those of the Northern Group in Prizren. Montenegrin troops stormed Tarabosh Mountain and the hills around Shkodra. The cannons of the Montenegrin forces started firing the first shells on the city on the morning of October 11 and, for more than six months, the bombings became a daily part of the life of the city. But it seems that those who attacked, had noticed that the city was well fortified and that it was run by a senior military man, who was undoubtedly one of the most prominent of the Turkish army. Referring to Russian documents for the Albanian National Movement in 1912, (2006, p. 256), in a summary of the reports of the actions that belonged to the dates 19, 20 and 21 October 1912, in the Balkan Peninsula, by the Russians, among other things it was written that the southern wing, which calculated to start bombing Tarabosh on October 16 , he was unable to do so because he was prevented from building a chariot road to approach the siege cannons and intends to start artillery fire only on October 21. The situation in the region was not at all favorable at the beginning of the siege and the situation inside the city was even worse. The troops of the Balkan powers had taken over the Turkish troops and the forces of the latter were suffering losses on almost the entire front. The King of Montenegro, Krajl Nikolla, was stationed in the encampment of his troops to encourage the army, led by Prince Danilo. The break-up of Turkish troops and the ceasefire that followed in December had allowed the Serbs to send more than 30,00o of their troops to reinforce Montenegrin troops. In fact, the fighting showed that this fortification around Shkodra, 
despite its shortcomings, was quite effective. Neither the Montenegrins nor the Serbs, despite the heavy losses they suffered, the Montenegrins 13,00o killed and the Serbs 5,00o, were unable to take any fortified region, with the exception of the two strongholds at Myselim and Lodërtuna. One of the reasons for these heavy losses and the inability of the Serbo-Montenegrins to penetrate the defense of Shkodra was their lack of knowledge and unpreparedness to take the fortified type regions. In the fighting with the Turkish and Albanian forces in the regions around the city they had not encountered such a modern and solid fortification for the time. Despite the individual values of the soldiers, the combat efficiency of the Serbo-Montenegrin armies in the siege of Shkodra, with the combat operations in the period October 1912 April 1913, was mediocre. There was a strong ambition among Montenegrins and mountaineers as to who would first enter in the Deçan fortress. According to researcher Edith Durham (1991) Montenegrin soldiers did not allow the name of the highlanders to be mentioned, claiming that they liberated Decic. Thanks to their blind faith, the Albanian highlanders joined the Montenegrins, giving the Montenegrin army an advantage in fighting. Without this help the Montenegrins would have had no result. The forces of Montenegro, as the researcher Durham writes, would not be able to take either Tuz or Shkodra.

\subsection{The Resistance of Ottoman troops in the city's defense}

The Shkodra garrison command had paid special attention to Tuzi's defense. This was the first serious obstacle in the direction of Shkodra. The main forces and vehicles were placed in defense, 5 battalions with regular soldiers, 2 battalions with ranks from Kavaja and Shkodra, about 3 thousand people. Montenegrin forces made a maneuver, attacking the Albanian-Turkish forces, defending Tuz, from the right wing and behind the back. The fall of Tuz was a great loss for the Shkodra garrison. Turkish troops withdrew, leaving only Albanian volunteers at the front. The war of Shkodra once again revealed the Albanian world with all the greatness and tragedy of its history. This war whitewashed the glorious past, the pain, the misery, the backwardness, the ability of the people not to bow down, the traditions, the customs, the psychology of a warrior people. The war took place between the Turkish military forces and the Albanian volunteers who were defending and the invading forces of the SerboMontenegrin army. Part of the highlanders of the Greater Malësia, forced to immigrate to Montenegro at the time of the 1911 uprising, had made a joint cause with Montenegro and participated in the war against the Turkish army. But the highlanders could not be used by the Montenegrins as a striking force to break through the paths towards Shkodra. The Montenegrins then attacked and fought on the backs of Albanian forces. The population of the city gave a special support and contribution to the strong fortification of Shkodra. It participated in the transportation of fortification materials to the destination, the construction of trenches, strongholds, the opening of new roads to the top of Mount Tarabosh and in Bardhaj i Madh, as well as the improvement of existing ones in Shtoj and Bërdicë. But, undoubtedly the most important factor was the determination of the people of Shkodra and the Albanian volunteers, who fought to defend their city and homeland. According to Austro-Hungarian documents of the time (Duka \& Egro 2012, p. 355), the condition of military fortifications and heavy weapons equipment during the first months of 1912, was below any level. Therefore, from the end of March 1912, a unit was sent, headed by the engineer Ismail Efendi, to ascertain the situation and to quickly renovate the fortresses in Senica, the New Bazaar and Berane. When controlling the cannons in the positions in Berane, Senica, New Bazaar, Prijepole and Pevle it turned out that all were in unusable condition for war, so they had to be replaced with others. Meanwhile, the government in Istanbul considered and believed more in the Shkodra Division, which had 12,0oo soldiers, and in the spring there was expected to be mobilized another division. The military circles in Shkodra generally believed that they were prepared for any possible surprise. In fact, the situation was not so optimal and hopeful as these military circles suggested. Land traffic for military transport was almost not used at all in the Shkodra sanjak, as deliveries by Austrian and Greek military ships coming from Istanbul and Thessaloniki were not used by the Italians. The storage of all supplies of ammunition and food was limited only in Shkodra and in addition to the warehouses in the old castle, there were such in two 
other localities. In Tuz there was a small warehouse for ammunition and one for food, while in Hoti there was a food depot, located inside a mountain gorge. According to Consul Zambaur: "at the ammunition deposits were for both the fieldarmy and the artillery of the 24 th Division. They were enough for many months, even in a state of war. Even the stocks of food items were sufficient, but they were not so well prepared. For this reason, in case of war and difficulty in supply, the lack of flour and animal feed was foreseen" (Duka \& Egro 2012, p. 227). So based on the quotations above, it is noticed that the Shkodra Division was the only one that was thought to be fully effective in time of war. But according to the French documents of the time, the figure of 800 people could be reached in the battalions with four companies, and up to 750 in the battalions with three companies (Shatri, 2012, p.108). According to the reports of Consul Zambaur, the Ottoman authorities, although right, in the interest of peaceful consolidation of the situation in the Vilayet of Shkodra did not take any action that could affect the sensitivity of the Christian Albanian population regarding the issue of military service (Duka \& Egro 2012, p. 209). Meanwhile, according to the Austro-Hungarian documents of the time, the Ottoman government, in addition to the Shkodra Garrison, reinforced several military posts at the border and one of the other measures it took was to close the barbed wire border. The Ottoman border posts had been ordered to shoot on any persons attempt to remove the barbed wire and cross it (Duka \& Egro 2012, p. 159).

\section{Albanians and the Fight for the Shkodra City Protection}

According to Austro-Hungarian documents of the time, the condition of military fortifications and heavy weapons equipment during the first months of 1912 was below any level, so by the end of March 1912, a unit was sent, headed by the captain of the engineer Ismail Efendi, to ascertain the situation and to quickly renovate the fortresses in Senica, the New Bazaar and Berane. When controlling the cannons in the positions in Berane, Senica, New Bazaar, Prijepole and Pevle it turned out that all were in unusable condition for war, so they had to be replaced with others (Duka \& Egro 2012). The General Command of the Turkish Army had planned to fight with the forces of the 7 th Corps or otherwise the Shkodra Corps, which consisted of the 24th Nizam Division in Peja, some border battalions and some regiments of Albanian reservists and volunteers in Prizren, Plava, Guci and Peja. 49 battalions with 53,718 men were counted (Rexhepi, 2001, p, 28). Volunteers from Dibra, Mati, Elbasan, Shijaku, Ndroqi, Kavaja, Tirana, Kruja, Lushnja, Devolli, Gramshi, Librazhd, etc. had also come to protect the city and its surroundings (Murzaku, 1987, p. 243). According to Turkish sources, Shkodra is defended by the Shkodra Corps, which is under the command of the Western Army. The Turkish command had long known that in the turmoil of the Balkan War, Montenegrin troops had only one mission, to subdue and occupy the Albanian city. For this reason, the Shkodra Garrison Command planned and implemented important measures for the protection of the city. One of them, which significantly affected the stability of the defense was the fortification of the defense regions and the use for defense of the castle of Shkodra, which, a year ago was reconstructed as an important object (Nikaj, 1917, p. 154). The territory to be fortified was divided into 4 areas, which were:

- The area of Fushë or the area of North Shodra, which started from the lake to the river Kir.

- The second area stretched from the Kir River in the East, which included part of the river to the hills, then climbed, including the Bardhaj hills.

- The third area or of Tarabosh mountain, which started from the lake, went up to the top of the mountain and went down to the river Buna. Whereas, the fourth area included the hills of Bërdicë and Vukatana (Çakmak 2005, p. 146). The siege of Shkodra would last more than 183 days and the battle for it would become one of the most famous in Europe at that time. With his headquarters in Bardhanjore, Hasan Riza Pasha did not know what would be the fate of the city at noon on October 11, 1912. That morning, of all the expected troops, only 10 thousand Rediffs and volunteers of Central Albania, inclined by Brigadier General Esat Toptani, had managed to enter the city. He did not expect any further aid and, with 15,0oo fighters, had to face a fierce siege of more than 25,000 Montenegrins and an auxiliary force of 
almost 30,00o Serbs who would soon join them.

The city continued to stand, but it was clear that the telegram of the Minister of Defense had put Hasan Riza Pasha in trouble. Convinced that resistance in the city should have a flag, he entered into treaties with Austria-Hungary. On the night of December 31, Hasan Riza Pasha received a direct message from the Albanian Prime Minister, explaining that the resistance in Shkodra was vital to the future of the city and inviting him to protect it under the Albanian flag. One of the reasons for the invincible resistance of the defense forces of the city of Shkodra, about 20,00o Albanian fighters and 4,00o Turkish soldiers, during the six-month siege by the troops of 7 Serbo-Montenegrin divisions in the First Balkan War, 1912-1913, according to participants in this war and its researchers, it was the fortification of the fighting theater. The fortification of Shkodra, as it was pointed out before, was built in accordance with the features of the mountainous, hilly and plain terrain and, especially with the great water obstacles, with which this city is rich, such as the lake of Shkodra, the rivers Drini , Buna and Kiri. On this basis was built the fortification system, divided into zones. Buildings made entirely of stone or of stone and earth were also built. Meanwhile, cart and decovil roads were built to transport ammunition. Facilities for the protection and preservation of drinking water were built, both in Tarabosh and Fushë e Shtoit that of cannons (Tucovic, 1948, p. 18). In conclusion, it should be noted that, until the beginning of the hostilities, on October 9, 1912, the fortified regions in Tarabosh, Shtoj and Bërdicë were generally built, but in none of them were the works completed to the planned extent. The area of Kiri was less fortified, the works in Bardhaj i Madh had started, while in Bardhaj i Vogël still not (History of the Albanian Army, 2000, p. 152). The first operations of the Montenegrin army around Shkodra, forced the defenders of the city to intensify the fortification works, which focused mainly on expanding and strengthening the shooting positions of infantry from standing, quite efficient in the fighting, especially in Shtoj and Tarabosh. The lack of fortifications in Bardhaj i Madh and Vogël posed a great danger to the city, also because the main forces of the Montenegrin Zeta Group attacked in that direction. Other trenches were built along the northern and southern slopes of Tarabosh, along with ditches. Since with the approach of the Montenegrin forces in Muriqan the greatest danger came from the direction of Oblika, a whole belt of trenches was built there, being further reinforced from the north. In addition, on the western side of Tarabosh and on some hills in the South and Southwest of Shiroka, trenches were built to strengthen the protection of this side. Wire barriers, in three or four rows, were placed along the entire length of the trenches on the slopes of Tarabosh. The entire fortification system was connected by telephone. Thankfully, the city resisted for another four months.

\subsection{The Commander Hasan Riza Pasha role in the resistance for the defense of Shkodra}

The approval of Austria-Hungary further mobilized the Catholic population of the city. Colonel Hasan Riza Pasha, Monsignor Sereqi, Alush Lohja and Esat Pasha, agreed to send two messages of help to the highlanders, through the Rubik Assembly. The messages, which were accompanied by the assurances of Monsignor Serreqi and those of Austria-Hungary, instructed the Catholic highlanders to attack the Montenegrin troops from behind, seeing that the Albanian flag was raised in the castle of Shkodra. The resistance of Shkodra, the end of the war and the Conference of Ambassadors began to create a situation not at all favorable for the Montenegrin armies. Realizing that the situation was going against them, the Montenegrins stepped up attacks and bombings, with the idea of subjugating the city and making it their own before the discussion on the northern borders began. Against the Russian will, the Conference of Ambassadors had recognized Albania's independence, but had made frightening "corrections" of its borders in favor of Serbia, Montenegro and Greece. Shkodra was envisaged in the Montenegrin area, but a short time later, Austria-Hungary and Italy were reminded that it was the center of Albanian Catholicism. Consequently, even with the help of England, they decided that the city should remain in Albania. The commander of the Turkish army Hasan Riza Pasha, a distinguished 
officer of the Turkish General Staff, has been a great soldier and endowed with all the qualities of a "high and good man". In the realization of the good fortification of Shkodra, a special role was played by the Commander of Shkodra Hasan Riza Pasha, who was acquainted with the German experience in this field after finishing a General Staff course in Berlin. Hasan Rizai himself highly valued the value of this fortification and in his opinion the Montenegrins could not take Shkodra. But, suddenly, the danger of the surrender of Shkodra by Esad Toptani appeared. At that time the situation in the city was aggravated and food, despite strong rationing, was no longer available. To this must be added the fact that much of the city had been devastated by the bombing and that there was no room for the wounded in hospitals - most of whom were civilians. Likewise, the defense troops had many losses from their ranks, although the stories of the time prove that the Montenegrins also had many killed. The idea of surrender had begun to circulate in the city, an idea that however was not said out loud. Meanwhile, the situation in the city had worsened. The famine had spread everywhere and more than half of the dead of the day were from starvation. The city had been destroyed and, according to chronicles of the time, volunteers from Central Albania had begun to boil leather "opinga" (leather shoes) and drink their juice. From Shkodra, the Austro-Hungarian Consul General, Zambauer, announced in November 1912 that Esad Pasha was ready to hand over Shkodra to Austria-Hungary, but Hasan Riza Pasha had objected to this (HHStA. PA. Report, 16.11.1912, file 22-8). Hasan Riza Pasha was mysteriously shot dead by three men, but the killers and the motives that led them to do so were never officially revealed. In 2014, Hooton expressed that he widely believed that the assassination was ordered by Esad Pasha who after the death of Hasan Riza took over the military troops, given that he was close to fulfilling his greatest ambition to lead a new Albanian state. The murder of the Turk "with an Albanian mother" as Edit Durham calls him (1903-1944), Hasan Riza Pasha who wanted to fight for the defense of Shkodra until the end and not to surrender to the Montenegrin army, led to the sale of Shkodra by Esad Pasha ( Xoxi, 1983, p. 333).

\section{The Surrender of the City by Esad Pasha Toptani}

On learning of the surrender of Shkodra, Ismail Qemali declared: If it is true that Esad Pasha left Shkodra with armies, weapons and artillery, then can be confirmed the trade made by King Nikola and Esad Pasha. He even called it, "Attempts against the independence of Albania" (Albanian Academy of Sciences, 2007, p. 37). The shameful act of handing over the city of Shkodra to the Montenegrins by General Esad Toptani is confirmed in his book by the Serbian author Batakoviç, who writes that the most suitable figure for this purpose was that of Esad Pasha Toptani, a Turkish general who surrendered Shkodra to the Montenegrins in April 1913 and was allowed in exchange to leave the city with his army and armaments to join the power struggle in Central Albania (Batakoviç, 2012, p. 13- 14). Researcher Margaret MacMillan (2013, p. 462) states that: Montenegrin King Nikola, corrupted one of the defenders of the City of Shkodra, the Albanian Officer of the Ottoman forces, to hand over the city to him. Referring to Crampton, she continues: "Esad Pasha, as deceitful and cunning as Nikola, first killed the garrison commander and then set a price of $80.000 \mathrm{f}$. After receiving the amount, he sent a message claiming that he had lost the suitcase sent by Nicholas with this amount and that in this way he claimed that the amount would be reimbursed once more (Crampton, 1977, pp. 370-390). The surrender took place on the morning of April 23 and, only after the last Albanian fighter left, the occupier raised his flag in Rozafa fortress. April 23 was the 183rd day of the siege. These days had marked over 3,500 killed and dead, several thousand injured or sick as well as a destruction of over 60 percent of the city. But, all these indicators together had eternally secured Shkodra a great name in the European chronicles. The Montenegrin army entered Shkodra 24 hours after Esad Pasha's troops had left. The latter, passing through Lezha and Milot, they arrived in Tirana. One week later, over 1,80o Turkish soldiers left by boat for Istanbul, while Central Albanian volunteers after a parade in Tirana were dispersed to their cities. But the stay of the Montenegrin forces in the city of Shkodra did not last long because, in fact, the Great Powers had already determined the fate of the city. It would remain part of the state of Albania and as a result, Montenegrin forces were forced out of the city, on May 14, 1913. Shkodra passed 
under the control of the International Squadron commanded by English Colonel Sesel Berney. Russia was also convinced about the resolution and determination of the fate of Shkodra as part of the Albanian territory. Her Foreign Minister Sazonov wrote about the case of the city of Shkodra: "To end the danger regarding the expected occupation of Shkodra by Serbs and Montenegrins and to appease our friends abroad, I stated that the view of the imperial government on this problem does not change, even if this invasion were to take place we will continue to call Shkodra as a predetermined area to become part of the independent Albania "(Glenny, 2007, p. 242).

\section{Results and Conclusions}

The Shkodra war proved that in the strategy and argument of the member states of the Balkan Alliance, in addition to the fight against the joint Ottoman occupier, was hidden the intention to occupy and annex many Albanian territories. Meanwhile, the development of this war united all the people, citizens and highlanders to defend the city, walking on new roads and overcoming countless difficulties and obstacles. The people of Shkodra, making their own positive legacy, raised the values of the Albanian people before all of Europe and the world to live free, independent and sovereign in their land. She proved that the people know how to preserve the national energies and consciousness, making history, showing the traditions, endurance, culture, vitality and determination that were imposed on the Great Powers and the Balkan monarchies of the time. Judging by its character and content, this war was not a separate phenomenon on the Albanian, Balkan and European level. Although it had distinctive features that are determined by the concrete historical conditions in which it took place, it was part of the fight for the independence of Albania and the protection of its territory. Although the Shkodra War ended with the surrender of the city by Esad Pasha, it left an indelible mark on the popular consciousness, but also in the international arena. The Shkodra War is one of the greatest heroic events and a basis for the subsequent wars of the Albanian people. In this war, some features in the application of military arts were used, unnoticed until then in the Albanian theaters of war. According to Kinross (2002) all these developments led to a London Conference during which the Great Powers would try to exert their influence against any claim of the Balkan states to realize themselves a peace treaty between them and the Turks. On January 1, 1913, the High Gate submitted its proposals for peace. These were mainly related to the status of Adrianople, the former capital of the Empire, which remained the only European city of the Empire - except Shkodra in Albania and Ioannina in Epirus - which quietly withstood their invaders. In the statement dated 7 April 1913, the English Secretary of State, Edward Gray (A. Pernice, Origine de evolucioni storica delle nazioni balcaniche 1915. Quoted in P. Rexhepi Defense of Shkodra 1912-1913, p. 197), It was said: "The war in Shkodra has ceased to have an effect on the fate of the war between Turkey and its Balkan allies, it has ceased to be a liberation war. "Montenegro's operations against Shkodra are part of a war for conquest and there is no reason not to give freedom and independence now to the Albanians of the Shkodra district, Catholics, Muslims, who are fighting for their land, for their existence. E. Gray's intervention was so decisive that were it not for the ingenious conciliatory intervention of the British Foreign Secretary, Sir Edward Gray, Durrës and Shkodra today would "enjoy" the sad name that Sarajevo has (Glenny 2007, p. 202). In the end, with the forced withdrawal of the invading Montenegrin military forces from the city of Shkodra, on May 4, 1913, things were clarified. According to the researcher Aubrey Herbert (2015) The First Balkan War ended on May 30, 1913, with the signing of the Treaty of London, according to which Turkey and the Balkan League agreed that the six Great Powers would take the responsibility for the formation of the Albanian state and the determination of its boundaries. But, until this conclusion, a difficult and tense week had to be overcome, in the European diplomacy, which had led to the forced withdrawal of Montenegro from Shkodra. Ten days later, an international peacekeeping force was deployed in the city torn apart by the Balkan Wars. Meanwhile, according to Kinross (2002), thanks to the allied forces of European nationalism, Turkey has ceased to be a power in Europe. The assessments and echoes of the Shkodra War, one of the longest of the two Balkan wars of 1912-1913, were numerous and varied. Most of them came from foreign political personalities, such 
as Italians, Austro-Hungarians, English, Russians, etc. The march of the defense forces and their weapons was so well organized that their fire suddenly appeared for the Montenegrin forces, so much so that the Serbian researcher Tucoviç (1948, p. 85) admits it when he writes: "When the fighting begins, it is not known where does the fire come from "! Another political personality, the Austro-Hungarian Foreign Minister, Berthold, through an instruction sent on December 25, 1912 to the Austro-Hungarian ambassador in St. Petersburg, instructed him to meet with the Russian Foreign Minister and to inform him that the invincible resistance in the defense of Shkodra was not so much a success of Turkish weapons as a test of the determination in which the Albanians fight to defend this city inhabited solely by their compatriots (Puto, 2012, p. 206). The Russian Foreign Minister Sazonov, on April 16, 1913, would declare that: "The concession we made (Decision of the Conference of Ambassadors in London of March 22, 1913, where Shkodra was decided to remain to Albania) was to maintain peace A war provoked for this reason would be a real absurdity, being Shkodra a mere Albanian city...Montenegro has not been able to assimilate several thousand of Albanians, Catholics and Muslims, who have been settled within its borders for 35 years previously (Albanian lands acquired from Montenegro according to the decisions of the Berlin Congress of 1878)". How to seal the opinion that Shkodra was held with a lot of selflessness, being one of the longest combat operations in the First Balkan War, the Italian Xhani Baj Makaria said that the city of Shkodra was defended mainly by Albanians, fierce and original fighting people, jealous of their freedom, proud of their traditions (Rexhepi, 2001, 197). The Shkodra War involves the longest defensive operation of the Balkan Wars, where the northern Albanian city could not be dealt with by Montenegrin invasive combat operations. In the defense of Shkodra, there is no doubt that proved to be decisive the fighting spirit and the fighting endurance of the Albanians and the forces of the Turkish garrison of the 24th Nizam Division, which faced the Montenegrin and Serbian forces with rare courage and selflessness for almost seven months. There are many assessments and opinions on this resistance force of the Albanians and on the importance of the fighting in this area. The city surrendered to the Montenegrins, but not because of submission to the adversaries' fighting and their military skills. The surrender was signed beyond any military resistance, violating the relentless heroism, over the blood and sacrifices of the defense fighters and the citizens of Shkodra. Especially when it was known that the city, since the middle of March 1913, had remained to Albania, the state that belonged to then and even nowadays.

\section{Analysis of the Archival Sources, Bibliography and Literature}

In this paper we used a qualitative comparative analysis of primary archival research resources, such as those secondary bibliography of literature, domestic and international, Russian, French, Austrian, Serbian, Italian, Turkish and British literature. The purpose of approaching these sources of qualitative historical research has been to reflect as much as possible the truth and objectivity of historical events and facts that occurred in relation to the issue of defense of the city of Shkodra during the Balkan wars of 1912-1913.

\section{References}

Albanian Academy of Sciences (2007). History of the Albanian People, Vol.III. Tiranë: Toena.

Barby Henry, (1913). Les Victoires Serbes, Publisher: Grasset.

Batakoviç T. T. D., (2012). Government of Serbia and Esat Pashë Toptani. Tiranë: IDK.

Biagini A., L'Italy and the Balkan Wars: Balkans at the start of the conflict (2012). Roma: Edizioni Nuova Cultura.

Çakmak F, (2005). How Western Rumelia was lost, (Translation). Tiranë: AIH.

Documentary summary The Provisional Government of Vlora and its activity, 28 November 1912-22 January 1914 (1963). Tiranë: Institute of History.

Duka F., Egro D., Gjermeni S., (2012). Albania in Austro-Hungarian Documents (1912), Volume II. Tiranë: Albanological Publications.

Durham, E, (1990). Concerns of the Balkans and other works for Albania and Albanians. Tiranë: 8 Nëntori.

Feçori R., (2002). Foreign armies in Albania. Tiranë: Ermal. 
Glenny M, (2007). History of the Balkans 1804-1999. Tiranë: Toena and IDK.

Hall R. C., (2000). The Balkan Wars 1912-1913, Prelude to the First Word War. Routledge.

Herbert A. (2015). The fall and fall of Albanian tyranny 1957 - 2010. Tiranë: UET Press.

History of Albania, Volume II. (1956). Tiranë: USHT publication.

History of Albanian martial art from Antiquity until 1939, (2001). Tiranë: SHBU.

History of the Albanian Army, 1912-1939, (Vol 1), (2000). Tiranë: SHBU.

Hooton E. R., (2014). Prelude to The First World War, The Balcan Wars 1912-1913, U.S.A.: Fonthhill Media Limited. Kadare I, Simiç P, Frckskoski L, Hysa Y, The South of Balkans, (200o). Tiranë: Onufri.

Këlcyra A, (2012). Writings on the history of Albania. Tiranë: Onufri.

Kinross L., (2002). The Ottoman Centuries, The rise and the fall of the Turkish Empire. New York 10022: Perennial, An Imprint of Harper Collins Publishers.

MacMillan M., (2013). The war that ended peace: How Europe abandoned peace for the First World War, London: Profile Books Ltd.

Murzaku Th., (1987). Serbia's policy towards Albania in 1912-1913. Tiranë: Institute of History.

Nikaj Dom N., (1917). Siege Shkodra, Tiranë.

Pernice A., (1915). The origin of the evolutionary history of the Balkan nations. Milan.

Puto A., (2012). Albanian independence and the diplomacy of the Great Powers. Tiraëa: Toena.

Rexhepi P., (2001). Defense of Shkodra. Tiranë: Globus R.

Sazonov D. S., (2009). Memories. (Translation). Tiranë: Helga`s Secrets.

Shatri M., (2002). French documents for Albania and Albanians in 1912. Vol.II. Tiranë: Toena.

Shatri M, Abdyli R., (2006). Russian Documents for the Albanian National Movement in 1912. San Pertersburg, 8/21 October 1912. Prishtina: Institute of History.

Tucoviq D, (1948). Serbs and Albanians. Prishtina: Rilindja 1948.

Xoxi K, (1983). Ismail Qemali - Life and works. Tiranë: 8 Nëntori. 